\title{
Green tea increases the survival yield of Bifidobacteria in simulated gastrointestinal environment and during refrigerated conditions
}

\author{
Dan C Vodnar and Carmen Socaciu*
}

\begin{abstract}
Background: The well-known prebiotics are carbohydrates but their effects may not always be beneficial, as they can also encourage the growth of non-probiotic bacteria such as Eubacterium biforme and Clostridium perfringens.

Therefore, new alternatives such as non-carbohydrate sources to stimulate the growth of probiotics are needed. The aim of this work was to evaluate (I) the green tea polyphenols by HPLC-LC/MS and (II) the protective effect of green tea extract on viability and stability of B. infantis ATCC 15697 and B. breve ATCC 15700 microencapsulated in chitosan coated alginate microcapsules during exposure to simulated gastrointestinal conditions and refrigerated storage.

Results: The major compound identified by HPLC-LC/MS in green tea was epigallocatechin gallate followed by caffeine and epigallocatechin. The survival yield of probiotic bacteria in microcapsules with $10 \% \mathrm{GT}$ during storage at $4^{\circ}$ $C$, demonstrated significantly $(\mathrm{P}<0.05)$ higher number of survival bacteria. Microencapsulated B.infantis and B. breve with $5 \%$ and $10 \%$ GT showed a significantly $(\mathrm{P}<0.05)$ improved survival under simulated gastric conditions ( $\mathrm{pH}$ 2.0, $2 \mathrm{~h}$ ) and bile solution (3\%, $2 \mathrm{~h}$ ) when they were compared with microencapsulation without GT addition.

Conclusions: The results of this study suggest that green tea coencapsulated with $B$. infantis or $B$. breve exert a protective effect of bacteria during exposure to gastrointestinal conditions and refrigerated storage. For a health perspective, the results confirm the growing interest probiotic bacteria and the perceived benefit of increasing their numbers in the gastrointestinal tract by microencapsulation.
\end{abstract}

Keywords: Green Tea, B. Infantis, B. Breve, Microencapsulation, Gastrointestinal conditions, Polyphenols

\section{Background}

The active delivery of probiotic cells in microencapsulated form has received reasonable attention during the last 10 years, since it can reduce losses of sensitive bacteria induced by detrimental external factors during storage and digestion [1]. Several reviews [2] summarized the potential of microencapsulation to improve probiotic survival during storage or gastrointestinal transit. Alginate is the most widely used matrix for microencapsulation, but its use is limited due to low stability in acidic conditions $[3,4]$. Therefore coating of alginate with chitosan improved the stability of alginate beads and thus improved the viability of the encapsulated probiotic bacteria, as previously shown by Krasaekoopt et al. [5].

\footnotetext{
* Correspondence: socaciucarmen@gmail.com

Food Science and Technology Department, Unit of Chemistry and Biochemistry, University of Agricultural Sciences and Veterinary Medicine, 3-5 Mănăştur str, Cluj-Napoca 400372, România
}

Bifidobacteria selectively colonize the intestinal tract of breastfed infants and are also relevant colonic bacteria in adults [6]. The strains commonly regarded as human probiotics belong to the species Bifidobacterium bifidum, $B$. breve, B. infantis, B longum, B. lactis and B. animalis, which are included in functional dairy products [6]. Bifidobacterium longum, B. adolescentis, and B. catenulatum are most commonly found in adult faecal samples while $B$. infantis and $B$. breve are predominantly present in infant's faeces [7]. Though, $B$. infantis and $B$. breve are also found in certain numbers in adults [8]. Strains of B. infantis are considered particularly beneficial due to its enhanced ability to inhibit gastrointestinal pathogens through direct anti-microbial action and to attenuate colitis [9].

Prebiotics are non-digestible carbohydrates that beneficially affect the host after ingestion as they are available as a selective energy source for probiotic Lactobacilli and Bifidobacteria, stimulating their growth and activity 
in the colon [10]. The effects of carbohydrate-type prebiotics may not always be beneficial, as they can also encourage the growth of non-probiotic bacteria. Bello et al. [11] demonstrated that the use of fructo-oligosacharides (FOS) resulted in enhanced growth of Eubacterium biforme and Clostridium perfringens. Therefore, new alternatives such as non-carbohydrate sources to stimulate the growth of probiotics are needed.

It is believed that the efficiency of probiotic health benefits can be enhanced by coupling the application of probiotics with a selective prebiotic growth substance, thus favoring colonization of probiotics in the human gut [12]. Hence, a combined application of pro- and prebiotics, a concept referred to as symbiotic, also emerged in the field of probiotic microencapsulation.

Green tea (Camelia sinensis) is one of the most widely consumed beverages in the world and has multiple health benefits, such as anti-stress [13], anticancer [14], antioxidant [15] and neuroprotective effects [16]. Green tea active polyphenols include (-)-epigallocatechin-3gallate (EGCG), (-)-epigallocatechin (EGC), (-)-epicatechin-3-gallate (ECG), and (-)-epicatechin [17].

In the present study, we evaluated (I) the green tea polyphenols by HPLC-MS and (II) the protective effect of green tea extract on viability and stability of $B$. infantis and B. breve microencapsulated in chitosan coated alginate microcapsules during exposure to simulated gastrointestinal conditions and refrigerated storage.

\section{Results and discussion}

\section{HPLC-LC/MS characterization of green tea extract}

Figure 1. shows a chromatogram of extracted green tea while the Table 1 lists the retention times, mass data, concentration and the substance names for the numbered peaks in the chromatogram. The compounds in tea infusion were identified with reference compounds and literature data on the basis of their HPLC retention times and mass spectra.

The dominant peak 7 in Figure 1, was identified as caffeine by processing the same retention time and mass spectrum, which had a $[\mathrm{M}+\mathrm{H}]^{+}$ion at $m / z 195$ Figure 2A. Peak $3,4,6,8,9,11$ were all identified as catechins belonging to the flavan-3-ol class of flavonoids. Peak 3 and 4 had a $[\mathrm{M}+\mathrm{H}]^{+}$ion at $m / z 307$ and according to the mass fragment ions were identified gallocatechin and epigallocatechin. Peak 6 was identified as catechin which had a $[\mathrm{M}+\mathrm{H}]^{+}$ion at $m / z 291$. Peak 9 showed a mass spectrum which corresponded with epigallocatechingalate Figure 2 C. Peak 11 had a $[\mathrm{M}+\mathrm{H}]^{+}$ion at $\mathrm{m} / z 443$ (Figure 2B) which clearly confirmed the catechingallate compound. Peak 1 and 2 were identified as phenolic acids according to the mass spectrum. Peak 1 produced the $[\mathrm{M}+\mathrm{H}]^{+}$ ion at 335 and mass fragment ions at $\mathrm{m} / \mathrm{z} 189$ and 171, which corresponded to quinic and gallic acid. Thus, peak 1 was identified as galloylquinic acid, peak 2 was confirmed as gallic acid. As can be seen in Table 1, the major compound in green tea extract was epigallocatechingalate $53.18 \mathrm{mg} / \mathrm{ml}$ followed by caffeine $19.16 \mathrm{mg} / \mathrm{ml}$ and epigallocatechin $7.13 \mathrm{mg} / \mathrm{ml}$.

\section{Microcapsules characteristics. Size, entrapment efficiency and viability}

Table 2. shows results for diameters and encapsulation yields of chitosan-coated alginate microcapsules containing $B$. infantis or B. breve with or without addition of green tea. The mean diameters of all types of microcapsules were between 318.23 and $344.19 \mu \mathrm{m}$. EY was higher for microcapsules with $B$. infantis as compared to all trials and low differences between microcapsules with $B$. breve, $\mathrm{B}+5 \% \mathrm{GT}$, $\mathrm{I}+10 \%$ GT. Some studies reported that encapsulation of

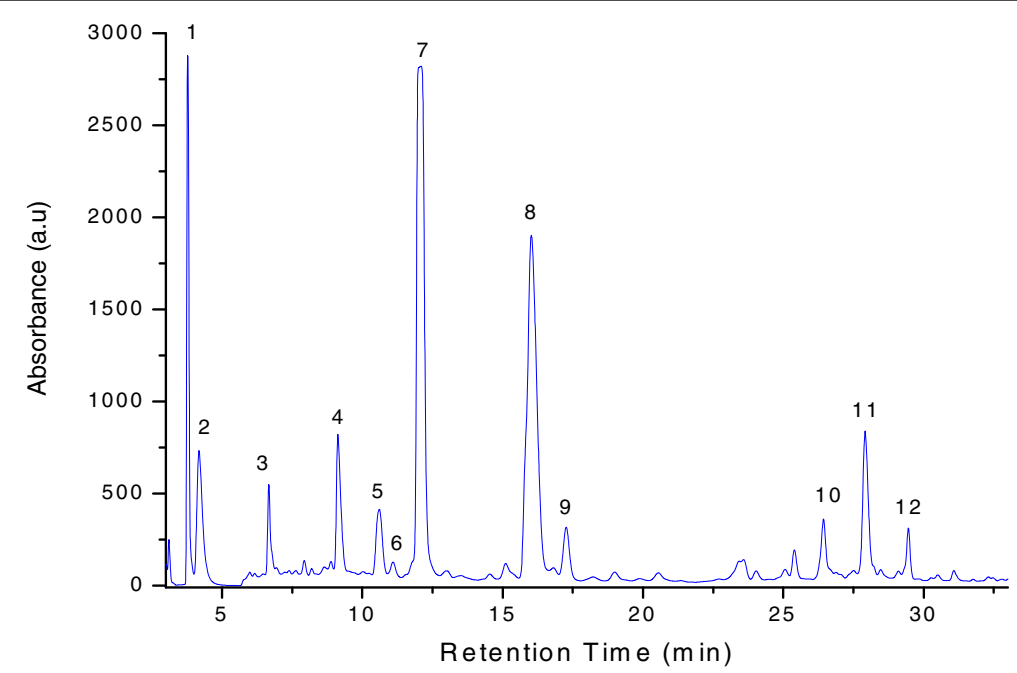

Figure 1 HPLC chromatogram of phenolic compounds in green tea extract. Peak numbers correspond to Table1. 
Table 1 Retention time, mass spectral data and concentration of phenolic compounds from green tea extract

\begin{tabular}{lcccc}
\hline Peak nr. & $\mathbf{R}_{\mathbf{t}}(\mathbf{m i n})$ & {$[\mathbf{M}+\mathbf{H}]^{+}(\mathbf{m} / \mathbf{z})$} & Compound & Concentration $\mathbf{~ m g} / \mathbf{m l}$ \\
\hline 1 & 3.77 & 335 & Galloylquinic acid & 6.18 \\
2 & 4.17 & 171 & Galic acid & 0.59 \\
3 & 6.66 & 307 & Gallocatechin & 4.5 \\
4 & 9.13 & 307 & Epigallocatechin & 7.13 \\
5 & 10.60 & 340 & Dicafeic acid & 0.32 \\
6 & 11.09 & 291 & Catechin & 1.59 \\
7 & 12.08 & 195 & Caffeine & 19.16 \\
8 & 16.02 & 291 & Epicatechin & 3.34 \\
9 & 17.26 & 459 & Epigallocatechingalate & 53.18 \\
10 & 26.42 & Ellagic acid & 0.82 \\
11 & 27.91 & Catechingallate & 3.29 \\
12 & 29.45 & 443 & Quercetin glucoside & 0.35 \\
\hline
\end{tabular}

probiotic bacteria with quercetin (prebiotic) has poor encapsulation efficiency and low viability of the cells in quercetin beads due to interaction of flavonoid with probiotic $[18,19]$. Our results showed difference between viability of bacteria in beads, increasing the viability of bacteria from microcapsules without GT (B: 9.24 log CFU/mL, I: 9.34 $\log \mathrm{CFU} / \mathrm{mL}$ ) to microcapsules with 5\% GT (B: 9.39 $\log$ CFU/mL, I: $9.28 \log$ CFU/mL) and 10\% GT (B: $9.43 \log$ CFU/mL, I: $9.36 \log$ CFU/mL), respectively.

\section{Survival of free and microencapsulated cells in SGJ}

Several studies have shown that only microencapsulated probiotics were able to maintain viability in gastrointestinal conditions [20]. Immobilization of bacteria in alginate beads has previously been tested for improving the viability of probiotic bacteria in simulated gastric conditions [21]. Sultana et al. [4] found the encapsulation of bacteria in alginate beads did not effectively protect the organism from high acidity. On the other hand, some authors reported the effect of alginate encapsulation on survival of lactic bacteria in simulated gastrointestinal conditions $[4,18]$, there is no uniformity in the reported results.

Viability of immobilized and free cells of probiotic bacteria with and without addition of GT, in simulated gastric juice was evaluated and the results were shown in Figure 3. Encapsulation in chitosan-coated alginate beads significantly $(\mathrm{P}<0.05)$ protected survival of $B$. infantis and $B$. breve. Microencapsulated $B$. infantis and $B$. breve with or without GT were resistant to simulated gastric conditions. In capsules without addition of GT, the survival rate of bacteria was lower comparing with the capsules containing 5\% and 10\% GT addition. Thus, the survivability rate increased proportionally with the concentration of GT addition. A significant differences $(\mathrm{P}<0.05)$ was noted between cell survival of $B$. breve with addition of $10 \%$ GT $v s$. all trials. Our results suggested that microcapsules with

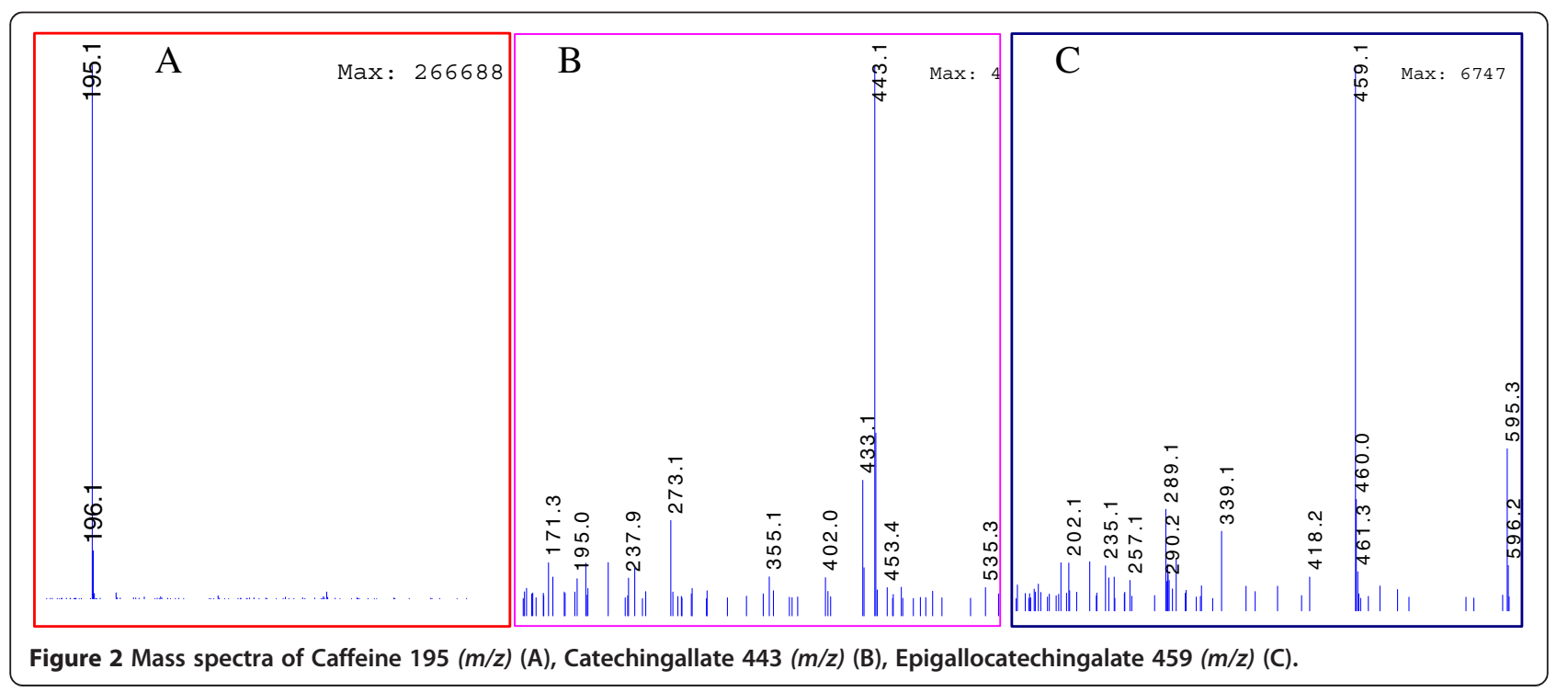


Table 2 Size, encapsulation yield and viability of bacteria in different beads containing green tea

\begin{tabular}{|c|c|c|c|}
\hline Beads Type & Beads Size $(\mu \mathrm{m} ; \mathrm{n}=50)$ & Encapsulation yield $(\% ; n=15)$ & Viability (log CFU/mL, $n=4)$ \\
\hline $\mathrm{I}+5 \% \mathrm{GT}$ & $344.19 \pm 1$ & $37.14 \pm 0.4$ & $9.28 \pm 0.3$ \\
\hline $\mathrm{I}+10 \% \mathrm{GT}$ & $339.1 .6 \pm 1$ & $35.33 \pm 0.7$ & $9.36 \pm 0.2$ \\
\hline $\mathrm{B}+5 \% \mathrm{GT}$ & $329.36 \pm 1$ & $37.18 \pm 0.4$ & $9.39 \pm 0.3$ \\
\hline $\mathrm{B}+10 \% \mathrm{GT}$ & $331.25 \pm 1$ & $36.15 \pm 0.7$ & $9.43 \pm 0.4$ \\
\hline । & $325.14 \pm 0.5$ & $38.24 \pm 0.5$ & $9.34 \pm 0.3$ \\
\hline B & $321.08 \pm 0.9$ & $37.24 \pm 0.8$ & $9.24 \pm 0.4$ \\
\hline $10 \%$ GT & $318.23 \pm 1$ & & \\
\hline
\end{tabular}

$5 \%$ and $10 \%$ GT extract increased the number of survival cells after $120 \mathrm{~min}$ of exposure to SGJ in comparation with microcapsules without GT addition. Thus, green tea exerts the stimulative effect on $B$. infantis and B. breve. It is estimated that $10^{7} \mathrm{CFU} / \mathrm{mL}$ of live probiotic cells are needed to confer health benefits to the consumer [22]. However, there was a rapid loss of free probiotic bacteria in SGJ, initial number of $9 \log \mathrm{CFU} / \mathrm{mL}$ for free strains decreased to less than $2.6 \log \mathrm{CFU} / \mathrm{mL}$ after exposure of $2 \mathrm{~h}$.

Some reports have indicated differences among strains of probiotic bacteria with respect to their survival in acid environment [23]. Krasaekoopt et al. [5] found that encapsulation with alginate coated with chitosan was the best treatment to protect studied bacteria for all conditions tested. Molan et al. [24] demonstrated the prebiotic effect of green tea containing selenium promoting the growth of Lactobacillus ssp. and Bifidobacterium ssp. under in vitro conditions. The mechanism by which tea extract increased the growth of probiotic bacteria remain unclear, a possible partial explanation for this enhancing effect was presented by Molan et al. [24] consisting on the ability of polyphenols in green tea, to act as antioxidant and antiradical agents, to modulate the oxidative stress in the medium generated by the metabolic activities and consequently provide a better environment for the growth and multiplication of strains.

\section{Survival of microencapsulated probiotic bacteria in SIJ}

Chitosan-coated alginate beads were the most effective in protecting probiotic bacteria from bile salt [19]. The chitosan coating provides protection in bile salt solution because an ion exchange reaction takes place when the beads absorb bile salt [25]. Krasaekoopt et al. [5] found that microencapsulation with alginate coated with chitosan was the best treatment to protect studied probiotic bacteria for all condition tested.

Viability of immobilized of free cells and B. infantis and $B$. breve with and without addition of (5\%,10\%) GT in simulated intestinal juice was evaluated and the results were shown in Table 3 . In the case of free $B$. infantis and $B$. breve, the initial average viable count of

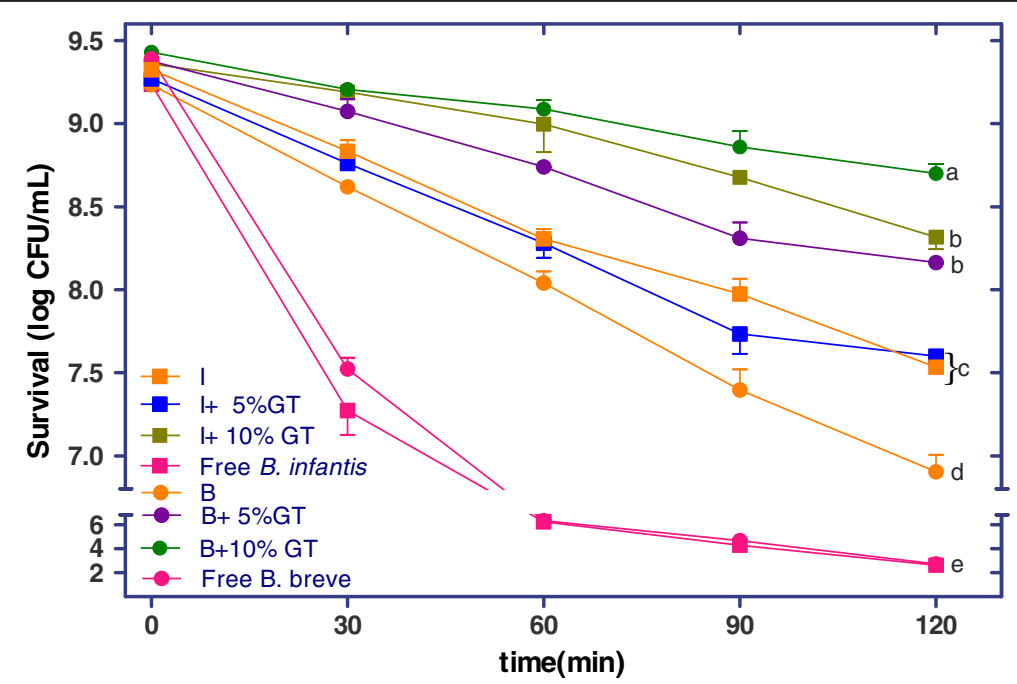

Figure 3 Survival of free and encapsulated B. infantis (I) and B. breve (B) with and without addition of $5 \%$ and $10 \%$ green tea (GT) during exposure to simulated gastric juice at $37^{\circ} \mathrm{C}$ for $120 \mathrm{~min}$. The error bars indicate standard deviations from the mean values of three replicated experiments. Means with different letter in a column are significantly different $(p<0.05)$. For abbreviations see Table 4. 
Table 3 Number of survival cells (log CFU/mL) during sequential incubation $\left(37^{\circ} \mathrm{C}\right)$ in simulated intestinal juice

\begin{tabular}{lllll}
\hline Beads Type & \multicolumn{4}{l}{ Simulated Intestinal Juice (SIJ) } \\
\cline { 2 - 5 } & $0 \mathrm{~min}$ & $60 \mathrm{~min}$ & $90 \mathrm{~min}$ & $120 \mathrm{~min}$ \\
\hline I +5\% GT & $8.85 \pm 0.3$ & $8.75 \pm 0.4$ & $8.20 \pm 0.5$ & $7.89 \pm 0.6$ \\
I +10\% GT & $8.99 \pm 0.1$ & $8.79 \pm 0.1$ & $8.48 \pm 0.6$ & $8.23 \pm 0.4$ \\
B + 5\%GT & $8.98 \pm 0.5$ & $8.64 \pm 0.6$ & $8.44 \pm 0.1$ & $7.46 \pm 0.8$ \\
B + 10\%GT & $8.87 \pm 0.7$ & $8.75 \pm 0.9$ & $8.68 \pm 0.5$ & $8.19 \pm 0.5$ \\
B & $9.04 \pm 0.3$ & $8.72 \pm 0.5$ & $8.03 \pm 0.4$ & $7.68 \pm 0.7$ \\
I & $9.11 \pm 0.6$ & $8.84 \pm 0.1$ & $8.15 \pm 0.7$ & $7.88 \pm 0.6$ \\
Free B. breve & $9.24 \pm 0.2$ & $6.81 \pm 0.8$ & $4.75 \pm 0.5$ & $2.45 \pm 0.4$ \\
Free B. infantis & $9.34 \pm 0.1$ & $6.93 \pm 0.1$ & $4.56 \pm 0.2$ & $2.89 \pm 0.3$ \\
\hline
\end{tabular}

9.24 $\log \mathrm{CFU} / \mathrm{mL}$ and $9.34 \log \mathrm{CFU} / \mathrm{mL}$ was reduced to $4.56 \log \mathrm{CFU} / \mathrm{mL}$ and $4.75 \log \mathrm{CFU} / \mathrm{mL}$ after $90 \mathrm{~min}$ and the average viable number was further reduced to $2.89 \log \mathrm{CFU} / \mathrm{mL}$ and $2.45 \log \mathrm{CFU} / \mathrm{mL}$ after $120 \mathrm{~min}$. The survival percentage of microencapsulated bacteria after exposure to SIJ for $120 \mathrm{~min}$ was highest in trials with $10 \%$ GT being $91.54 \%$ and $92.33 \%$ from the initial cell population found in encapsulated I+ GT $10 \%$ and B + GT $10 \% .10 \%$ GT exert a positive effect on survivability of probiotic bacteria after $120 \mathrm{~min}$ of SIJ exposure, enhancing the number of $B$. infantis with $5.05 \%$ and $B$. breve with $7.38 \%$ when was coencapsulated with them.

\section{Resistance to refrigerated storage}

Experiments were performed in order to evaluate the efficiency of immobilization treatment for increasing the probiotics viability under refrigeration. The results of the $B$. infantis and B. breve survival of with and without addition of green tea extract under 30 days of incubation at $4 \pm 1^{\circ} \mathrm{C}$ are presented in Figure 4 . Results showed that at the end of this time, the immobilized cells in 10\% GT had the lowest loss of viability $(0.94 \log \mathrm{CFU} / \mathrm{mL}$ for $B$. infantis and $0.82 \log \mathrm{CFU} / \mathrm{mL}$ for B. brevis). The viability of microencapsulated cells showed different stability between microcapsules with or without GT in the same storage conditions. After 30 days, the survival of free $B$. infantis and $B$. breve decreased from $3.5 \times 10^{9}$ to $3.4 \mathrm{x}$ $10^{7} \mathrm{CFU} / \mathrm{mL}$ and from $2.4 \times 10^{9}$ to $3.1 \times 10^{7} \mathrm{CFU} / \mathrm{mL}$ respectively. The number of microencapsulated bacteria with $10 \%, 5 \%$ GT was significantly higher $(\mathrm{P}<0.05)$ than microencapsulated bacteria without GT and free bacteria. The rate of decrease was significantly different $(\mathrm{P}<0.05)$ between the microencapsulated with and without $10 \%$ GT. Koo et al. [26] reported that probiotic bacteria loaded in chitosan-coated alginate microcapsules showed higher storage stability than free cell culture. We also observed a similar effect in our study. One of the properties for a given microorganism to be considered probiotic is its capacity to survive storage as a formulated product. In general, fermented products containing added probiotics should be stored under refrigeration at $4^{\circ} \mathrm{C}$. Our results, suggest that immobilization of $B$. infantis and $B$. breve with GT improve viability of probiotics during refrigeration storage

\section{Conclusions}

The results of this study clearly show that the major compounds in green tea are epigallocatechin gallate followed

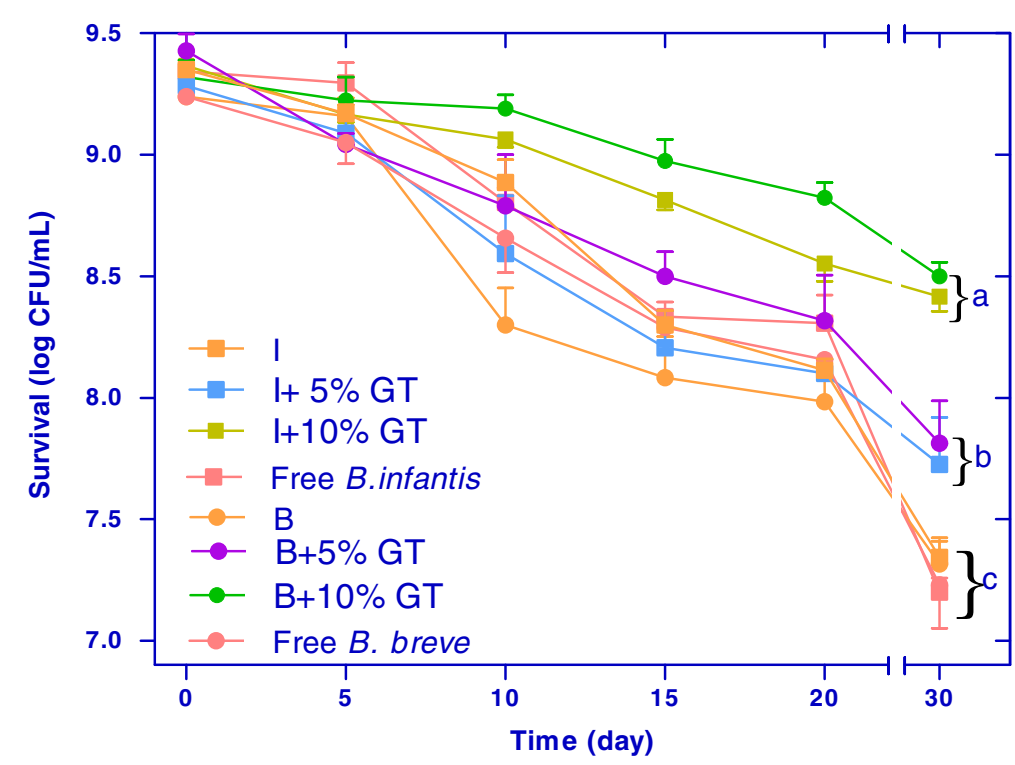

Figure 4 Survival of $B$. infantis (I) and B. breve (B) with and without addition of $5 \%$ and $10 \%$ green tea (GT) under refrigerated storage $\left(\mathbf{4} \pm 1^{\circ} \mathbf{C}\right)$. Means $(n=3) \pm S D$. Means with different letter in a column are significantly different $(p<0.05)$. For abbreviations see Table 4. 
by caffeine and epigallocatechin. 5\%, 10\% green tea coencapsulated in chitosan coated alginate beads, exert a stimulative effect on $B$. infantis and B. breve. The microencapsulation with $10 \%$ green tea $(\mathrm{w} / \mathrm{v})$ was more effective in maintaining the bacteria stability and increased their viability by storage at refrigeration temperature during 30 days. Also, green tea, significantly improved the bacterial survival in simulated gastrointestinal environment, and allows viable cells reach a beneficial level of probiotic. In conclusions, green tea microcapsules with probiotic bacteria offers an effective way to increase the life-spam and survivability in simulated gastrointestinal juices and maintaining their survival during refrigerated storage. For a health perspective, the results confirm the growing interest in probiotic bacteria and the perceived benefit of increasing their numbers in the gastrointestinal tract.

\section{Methods}

\section{Preparation of tea extracts}

Green tea (GT) was purchased from an online shop and is presently available on the market. GT is originally from China and the content of total polyphenols was reported on the prospectus as $40 \%$. The aqueous extracts were made by adding $10 \mathrm{ml}$ water $\left(100^{\circ} \mathrm{C}\right)$ to $0.1 \mathrm{~g}$ or $0.2 \mathrm{~g}$ tea leaves and brewing for $10 \mathrm{~min}$ with stirring and removing solid matter by filtration.

\section{Chemical characterization of green tea extract}

The chromatographic system used was an HPLC-DAD Agillent Technology (USA) series 1200 coupled with LC/ MS single-quadrupole mass spectrometer equipped with a pneumatically assisted ESI source. The column was a Eclipse XDB-C18, 150x4,6 mm, $(5 \mu \mathrm{m})$ from Agillent (USA). The phenols were separated with a mobile phase consisting of $1 \%(\mathrm{v} / \mathrm{v})$ formic acid (mobile phase A) and acetonitril (mobile phase B). A gradient run was started at $90 \%$ gradient $\mathrm{A}$, decreasing in $30 \mathrm{~min}$ to $75 \%$, further decreasing to $10 \%$ in $15 \mathrm{~min}$ and then back to $90 \%$ in $10 \mathrm{~min}$. Total run for each sample was $55 \mathrm{~min}$. The flow rate was $0.5 \mathrm{ml} / \mathrm{min}$. The diode array detector was set to acquisition range of 200-600 nm. The HPLC effluent entered the mass spectrometer through an electrospray capillary set at $3.0 \mathrm{kV}$ at a source block temperature of $100^{\circ} \mathrm{C}$ and a desolvation gas temperature of $350^{\circ} \mathrm{C}$. Nitrogen was used at flow rate of approximately $8 \mathrm{~L} / \mathrm{min}$. The mass spectra between $\mathrm{m} / \mathrm{z} 100$ and 600 , were obtained at a scan speed of $250 \mathrm{~m} / z$.

\section{Bacterial strains and culture condition}

Bifidobacterium infantis ATCC 15697 and Bifidobacterium breve ATCC 15700 were purchased in lyophilized form Bioaqua, Romania. Bacteria were routinely grown in MRS broth. Shortly, freeze-dried cells were inoculated into $5 \mathrm{~mL}$ MRS (de Man, Rogosa, Sharpe) broth (Merck,
Germany) and incubated at $37^{\circ} \mathrm{C}$, for $24 \mathrm{~h}$ under anaerobic conditions, and afterwards sub-cultured into $95 \mathrm{~mL}$ broth and incubated under the same conditions. The cells were harvested by centrifugation at $3000 \mathrm{~g}$ for $5 \mathrm{~min}$ at $4^{\circ} \mathrm{C}$ washed twice with sterile $0.9 \%(\mathrm{w} / \mathrm{v})$ sodium chloride solution and resuspended in $2.5 \mathrm{~mL}$ of sodium chloride solution $0.5 \%(\mathrm{w} / \mathrm{v})$.

\section{Microencapsulation and coating procedures}

The method described by Sheu and Marshall [27] was adopted for microencapsulation of bacteria strains. The water-GT extract was mixed with $20 \mathrm{~g} / \mathrm{L}$ of sodium alginate powder (Promova Biopolymer Norway), and sterilized. The cell suspension $\left(2.1 \times 10^{9} \mathrm{CFU} / \mathrm{mL}\right)$ were used as free cells or were aseptically mixed with $10 \mathrm{~mL}$ of $2 \%(\mathrm{w} / \mathrm{v})$ alginate solution containing or not $5 \%$ or $10 \%$ Green Tea (GT) extract, (Table 4) and were applied to the immobilization system. The chitosan and sodium alginate solutions were prepared according to Krasaekoopt et al. [28]. Briefly, the beads were immersed in $100 \mathrm{~mL}$ of chitosan solution $0.4 \%$ (w/v) and shaken at $100 \mathrm{rpm}, 37^{\circ} \mathrm{C}$ for $40 \mathrm{~min}$ on an orbital shaker for coating. The chitosan- coated alginate beads were collected by centrifugation $(500 \mathrm{rpm}, 10 \mathrm{~min}$ at $4^{\circ} \mathrm{C}$ ). The microcapsules were washed twice with $0.9 \%$ $(\mathrm{w} / \mathrm{v})$ sodium chloride solution and ressuspended in $50 \mathrm{~mL}$ of $0.5 \%(w / v)$ sodium chloride solution.

\section{Survival assay and numeration of microencapsulated bacteria}

Entrapped bacteria were released by homogenizing $1 \mathrm{~mL}$ of bead suspension in $9 \mathrm{~mL}$ of sodium citrate $0.1 \mathrm{M}$ for $10 \mathrm{~min}$, stirred diluted and poured in MRS agar plate. The plates were incubated 2 days at $37^{\circ} \mathrm{C}$, and the released bacteria enumerated as CFU/mL. The encapsulation yield (EY), which is a combined measurement of the efficacy of entrapment and survival of viable cells during the microencapsulation procedure, was calculated as: $E Y=\left(\mathrm{N} / \mathrm{N}_{\mathrm{o}}\right) \times 100 . \mathrm{N}$ is the number of free living cells released from the microcapsules, and $\mathrm{N}_{\mathrm{o}}$ is the number of free cells added to the biopolymer mix during

\begin{tabular}{ll}
$\begin{array}{l}\text { Table } 4 \text { Chitosan coated alginate beads with bacteria and } \\
\text { green tea }\end{array}$ & Abbreviation \\
\hline Trials & I $+5 \%$ GT \\
\hline Beads with $5 \%$ Green Tea and B. infantis & I +10\% GT \\
Beads with 10\% Green Tea and B. infantis & B +5\% GT \\
Beads with 5\% Green Tea and B. breve & B + 10\% GT \\
Beads with 10\% Green Tea and B. breve & I \\
Beads with B. infantis & B \\
Beads with B. breve & $10 \%$ GT \\
Beads with 10\% Green Tea &
\end{tabular}

The trials abbreviations are presented. 
the production of microcapsules. The particle size and formation of microcapsules were measured with a light microscope (Axio, Observer A1, Zeiss). The data analysis was performed using software UTHSCSA (University of Texas Health Science Center, San Antonio) Image Tool software (University of Texas Health Science Center, San Antonio, TX, USA).

\section{Resistance to gastrointestinal conditions}

Simulated gastric juice (SGJ) consisted of $9 \mathrm{~g} / \mathrm{L}$ of sodium chloride containing $3 \mathrm{~g} / \mathrm{L}$ of pepsin with $\mathrm{pH}$ adjusted to 2.0 with hydrochloric acid. $1 \mathrm{~mL}$ of cell suspension of B. infantis or B. breve were mixed in $9 \mathrm{~mL} \mathrm{SGJ}$ and incubated for $30,60,90$ and $120 \mathrm{~min}$ at $37^{\circ} \mathrm{C}$ with constant agitation of $50 \mathrm{rpm}$.

Simulated intestinal juice (SIJ) was prepared by dissolving bile salts (Oxoid, Basingstoke, UK) in intestinal solution $\left(6.5 \mathrm{~g} / \mathrm{L} \mathrm{NaCl}, 0.835 \mathrm{~g} / \mathrm{L} \mathrm{KCl}, 0.22 \mathrm{~g} / \mathrm{L} \mathrm{CaCl}{ }_{2}\right.$ and $\left.1.386 \mathrm{~g} / \mathrm{L} \mathrm{NaHNO}_{3}\right) \mathrm{pH} 7.5$ to final concentrations of $3.0 \mathrm{~g} / \mathrm{L}$ (Chavarri et al., 2010). Triplicate samples were mixed, incubated at $37^{\circ} \mathrm{C}$ and sampled 30, 60, 90, 120 min after addition of cell suspension. Surviving bacteria were numerated by pour plated counts in MRS agar incubated at $37^{\circ} \mathrm{C}$.

\section{Resistance to refrigerated storage}

The viability of probiotic bacteria under refrigeration was evaluated by incubating $1 \mathrm{~mL}$ (approximatively $3.8 \mathrm{x}$ $10^{9}$ cells $/ \mathrm{mL}$ ) of free and immobilized cell suspension in $9 \mathrm{~mL}$ of $5 \%(\mathrm{w} / \mathrm{v})$ sterile sodium chloride solution. Aliquots of $1 \mathrm{~mL}$ were taken every day for 30 days to determine the total number of viable cells.

\section{Statistical analysis}

Results for 3 individual experiments were used to calculate the mean of cell counts. Analysis of variance (ANOVA) and Duncan's multiple range tests were performed to analyze the results. Significance of difference was defined at the $5 \%$ level $(\mathrm{P}<0.05)$. All statistical analysis was carried out using Graph Pad Version 4.0 (Graph Pad Software Inc; San Diego, CA, USA).

\section{Competing interests}

The authors declare that they have no competing interests.

\section{Acknowledgements}

This work has supported by a research grant of University of Agricultural Sciences and Veterinary Medicine, Cluj-Napoca.

\section{Authors' contributions}

CS carried out the chemical composition of green tea extract taking into consideration the separation and quantification of extracts. DV contributed to the microencapsulation experimental work, exposure to simulated gastrointestinal juices and refrigerated storage. All authors read and approved the final manuscript.
Received: 11 May 2012 Accepted: 22 June 2012

Published: 22 June 2012

\section{References}

1. Anal AK, Singh H: Recent advances in microencapsulation of probiotics for industrial applications and targeted delivery. Trends Food Sci Tech 2007, 18:240-251.

2. Heidebach T, Leeb E, Först P, Kulozik U: Microencapsulation of probiotic cells. USA: CRC-Press/Taylor and Francis; 2010.

3. Adhikari K, Mustapha A, Grun IU, Fernando L: Viability of microencapsulated bifidobacteria in set yogurt during refrigerated storage. J Dairy Sci 2000, 83:1946-1951.

4. Sultana K, Godward G, Reynolds N, Arumugaswamy R, Peris P, Kailasapathy $K$ : Encapsulation of probiotic bacteria with alginate-starch and evaluation of survival in simulated gastrointestinal conditions and in yoghurt. Int J Food Microb 2000, 62:47-55.

5. Krasaekoopt W, Bhandari B, Deeth H: Evaluation of encapsulation techniques of probiotics for yoghurt. Int Dairy J 2004, 13:3-13.

6. Chow J: Probiotics and prebiotics: a brief overview. J Renal Nutr 2002, 12:76-86.

7. Matsuki T, Watanabe K, Fujimoto J, Kado Y, Takada T, Matsumoto K, Tanaka R: Quantitative PCR with 16 S rRNA gene-targered speciesspecific primers for analysis of human intestinal bifidobacteria. Appl Env Microb 2004, 70:167-173.

8. Ben-Amor K, Heilig H, Smidt H, Vaughan EE, Abee T, de Vos WM: Genetic diversity of viable, injured and dead fecal bacteria assessed by fluorescence-activated cell sorting and $16 \mathrm{~S}$ rRNA gene analysis. Appl Env Microbi 2005, 71:4679-4689.

9. Gibson GR, Wang X: Regulatory effects of bifidobacteria on the growth of other colonic bacteria. J Appl Bact 1994, 77:412-420.

10. Ziemer CJ, Gibson GR: An overview of probiotics, prebiotics and synbiotics in the functional food concept: perspectives and future strategies. Int Dairy J 1998, 8:473-479.

11. Bello FD, Walter J, Hertel C, Hammes WP: In vitro study of prebiotic properties of levan-type exopolysaccharides from Lactobacilli and nondigestible carbohydrates using denaturing gradient gel electrophoresis. Syst Appl Microb 2001, 24:232-237.

12. Gibson GR: From probiotics to prebiotics and a healthy digestive system. J Food Sci 2004, 69:M141-M143.

13. Kimura K, Ozeki M, Juneja LR, Ohira H: I-Theanine reduces psychological and physiological stress responses. Biol Psychol 2007, 74:39-45.

14. Lambert JD, Sang S, Hong J, Yang CS: Anticancer and anti-inflammatory effects of cysteine metabolites of the green tea polyphenol, (-)-epigallocatechin-3- gallate. J Agric Food Chem 2010, 58:10016-10019.

15. Hurst WJ, Krake SH, Bergmeier SC, Payne MJ, Miller KB, Stuart DA: Impact of fermentation, drying, roasting and Dutch processing on flavan-3-ol stereochemistry in cacao beans and cocoa ingredients. Chem Central $\lrcorner$ 2011, 5:53.

16. Weinreb O, Mandel S, Amit T, Youdim MB: Neurological mechanisms of green tea polyphenols in Alzheimer's and Parkinson's diseases. J Nutr Biochem 2004, 15:506-516.

17. Yang CS, Landau JM: Effects of tea consumption on nutrition and health. J Nutr 2000, 30:2409-2412.

18. Iyer C, Kailasapathy K: Effect of co-encapsulation of probiotics with prebiotics on increasing the viability of encapsulated bacteria in simulated gastrointestinal conditions and in yoghurt. J Food Sci 2005, 70: M18-M23.

19. Chávarri M, Marañón I, Ares R, Ibáñez FC, Marzo F, Villarán MC: Microencapsulation of a probiotic and prebiotic in alginate chitosan capsules improves survival in simulated gastro-intestinal conditions. Int J Food Microbiol 2010, 142:185-189.

20. Chandramouli V, Kailaspathy K, Peiris P, Jones M: An improved method of microencapsulation and its evaluation to protect Lactobacillus spp. in simulated gastric conditions. J Microb Meth 2004, 56:27-35.

21. Ding WK, Shah NP: Effect of various encapsulating materials on the stability of probiotic bacteria. J Food Sci 2009, 74:M100-M107.

22. Ouwehand AC, Salminen SJ: The health effects of cultured milk products with viable and non-viable bacteria. Int Dairy J 1998, 8:749-758.

23. Kailasapathy K: Survival of free and encapsulated probiotic bacteria and effect on the sensory properties of yoghurt. Food Sci Tech 2005, 1:1-2.

24. Molan AL, Flanagan J, Wei W, Moughan PJ: Selenium-containing green tea has higher antioxidant and prebiotic activities than regular green tea. Food Chem 2009, 114:829-835. 
25. Murata Y, Toniwa S, Miyamoto E, Kawashima S: Preparation of alginate gel beads containing chitosan salt and their function. Int J Pharma 1999, 176:265-268.

26. Koo S, Cho Y, Huh C, Baek Y, Park J: Improvement of the stability of Lactobacillus casei YIT 9018 by microencapsulation using alginate and chitosan. J Microb Biotech 2001, 11:376-383.

27. Sheu TY, Marshall RT: Microentrapment of lactobacilli in calcium alginate gels. J Food Sci 1993, 54:557-561.

28. Krasaekoopt W, Bhandari B, Deeth $\mathrm{H}$ : The influence of coating materials on some properties of alginate beads and survivability of microencapsulated probiotic bacteria. Int Dairy J 2004, 14:737-743.

doi:10.1186/1752-153X-6-61

Cite this article as: Vodnar and Socaciu: Green tea increases the survival yield of Bifidobacteria in simulated gastrointestinal environment and during refrigerated conditions. Chemistry Central Journal 2012 6:61.

\section{Publish with ChemistryCentral and every scientist can read your work free of charge \\ "Open access provides opportunities to our colleagues in other parts of the globe, by allowing anyone to view the content free of charge." \\ W. Jeffery Hurst, The Hershey Company. \\ - available free of charge to the entire scientific community \\ - peer reviewed and published immediately upon acceptance \\ - cited in PubMed and archived on PubMed Central \\ - yours - you keep the copyright \\ Submit your manuscript here: \\ http://www.chemistrycentral.com/manuscript/<smiles>c1ccccc1</smiles> 